\title{
Designing Rotationally Symmetric Products for Multi-variant Mass Production by Using Production-Technical Solution Space
}

\author{
Guenther Schuh, Till Potente, Christina Thomas, and Stephan Schmitz \\ Laboratory for Machine Tools and Production Engineering at Aachen University \\ Steinbachstrasse 19, 52074 Aachen, Germany \\ \{g.schuh, t.potente, c.thomas, st.schmitz\}@wzl.rwth-aachen.de
}

\begin{abstract}
Highly customized products have led to an irreproducible complexity in product development and order processing process. Today's product design and IT-tools reduce this complexity insufficiently and potentials in administration and manufacturing are not fully lapped. The approach presented in this paper starts the development of a product structure at the manufacturing environment. The aim is to develop a product structure for rotational products that is adapted for manufacturing processes and therefore enabling a costeffective production. As a result, companies are able to provide their customers with individual product solutions using standardized processes. This enables a technological and production-related flexibility to fulfill growing needs of global markets.
\end{abstract}

Keywords: production-oriented design, product development process, constituent product features, constituent process characteristics, order processing process.

\section{Introduction}

Engineering, process planning and mechanical manufacturing of single and small series manufacturer are facing a high variance of products, labile batch sizes and customer requirements today. Especially companies in the machinery and plant engineering industry producing powertrain and transmission technology are faced with highly individual customer requirements within rotational symmetric products. The companies challenge is to develop competitive products at cost-effective conditions based on existing production processes and products. The aim of this paper is to present an approach, which identifies constituent process features in manufacturing and matches it to the product features. These constituent process features are derived from critical process characteristics. Combined with the constituent product features they are used to establish product development guidelines. The solution is a basis for realizing a cost-effective product design and stable manufacturing. 


\section{Complexity and Interface Problems in Order Fulfillment and Product Development Process}

\subsection{Technical Challenge Due to Product Complexity}

Structural marginally different individual product components - with up to 1000 variations - lead to a high product and process diversity, causing huge fluctuations at the assignment of operation facilities. Figure 1 shows the analysis of process variance regarding the processing time. WZL (Werkzeugmaschinenlabor - Laboratory for Machine Tools and Production Engineering) Industry cases show companies which have more than 90.000 components and over 35.000 products in their portfolio [1]. Even if there are similarities at the product components, cost savings within the product development process and a cost-effective order processing process is not realized. The technical challenge is that due to the complexity and the lack of an evaluation engineers do not have the possibility to systematically chose a more costeffective and production-oriented constructive solution. The expense and cost influence of the process characteristics in manufacturing because of customized product features is not obvious to the engineer within the design phase.
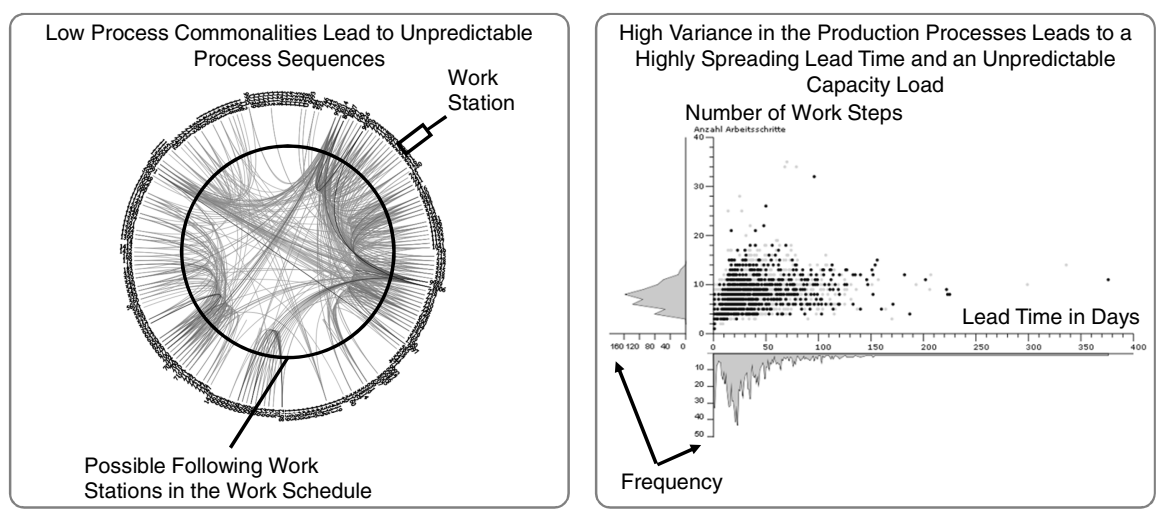

Fig. 1. Process Commonalities and Spread of Lead Time of a Production System (Source: WZL RWTH industry cases)

\subsection{Interfaces and Semantic Problems in Product Development and Order Processing Process as Research Question}

In the order processing product engineers, process engineers and manufacturer have different information and views on the product [2]. The high level of division of labor in the industry led to a partition of planning, executing and controlling functions and finally to a very sequential working method, which is mostly based on expert knowledge [1]. The research challenge is about a common understanding of designing product features and their impact on planning and manufacturing. The semantic is actually not able to link engineers knowledge with the needs and requirements of 
production engineers and manufacturer. Engineers, production engineers and manufacturer all together do not have a common understanding of the product features and the process characteristics because it is insufficiently defined which properties fully describe a rotational symmetric product in their single view.

\subsection{Not Realized Potential in the Product Development and Order Processing Process}

In single and small series manufacturing of machinery and plant engineering, shop fabrication is the dominant manufacturing principle. A various number, often more than 100 different resources, especially the mechanical fabrication such as turning, drilling and milling, is at disposal for the product creation [3]. The increased productcomplexity and partly nominal varying product features lead to a high amount of planning and coordinating activities within the order fulfillment process. This results in strewing machining times and total process times within the manufacturing process. Potential analysis and valuations by the industry clarify, that a reduction of product construction by $11 \%$, planning duration by $30 \%$ and cutting of the processing time in mechanical manufacturing by $60 \%$ [4], are possible saving potentials. This potential demonstrates the industrial relevance of the addressed problem.

\section{State of the Art in Product Development and Supporting the Order Processing Process}

\subsection{Deficits in Existing Approaches in Product Design}

Existing product design methods start at the market needs and do not or not sufficiently consider manufacturing process needs and their influence on the product development.

- Most existing approaches stay on a very functional level in describing product development processes. For designing more cost-effective and innovative products mostly platform and modularity of product architecture approaches are used. Existing approaches disregard the needs of manufacturing and production processes [5-12].

- Market-driven approaches develop methods to design product families and architectures. Concerning market needs and the product communality these approaches aim at profitable product platform regarding manufacturing and redesign costs. Nevertheless these methods do not consider the impact of product features on process features. [13,14]

- The approach of technology push bases the product design on the existing technologies within a company. Generally these approaches are on a more strategic level and do not give detailed solutions to design a product using the productiontechnical solution space. $[15,16]$

- Another approach integrates the different company divisions systematically in the platform development process. This method focusses on variance sensitive 
manufacturing processes to derive constituent product features for the product design. Nevertheless this method is not specific enough to state definite process features and their influence on product design.[17,18]

\subsection{Deficits in Supporting Engineering and Development and Industrial Engineering}

To support the product development process and the order fulfillment process there are a lot of IT-Tools, such as ERP-, PDM- and CAx-systems [19-21]. It can be stated that there is a certain discharge of routine jobs through the use of current IT-support within the order procedure process. Although single IT-solutions work fairly well, today's IT-support with its interface problems amplify isolated applications and a solid structure of company's divisions [2, 22]. Important information about product design and its impact on the process chain in manufacturing are not sufficient presented by these tools. For example product design is supported by using CADsystems, which are also used to create drawings for manufacturing. Nevertheless these drawings are not synchronized with the needs of manufacturing. After all important manufacturing information is not included in CAD-systems.

\subsection{Deficits of Existing Approaches to Control the Complexity within the Product Development Process}

Existing methods of product design and IT-systems do not support the product development and order processing processes in that way, that the stated potentials (see chapter 2.3). Critical process characteristics are not systematically detected and linked to product features yet. The reason for that is a very large number of different process parameters and their interaction. It is necessary to identify the main process characteristics e.g. diameter of components, machine tools, which have the greatest impact on administrative expenses and cost-effectiveness in manufacturing. Quantifying the influence of changing product features at the process chain in manufacturing is a perquisite to set product design guidelines for engineers.

\section{$4 \quad$ Using Production-Technical Solution Space to Design a Product Structure}

As one can see existing tools increase division's product and process knowledge in the product development process insufficiently. Therefore the actual challenge is not to design another supporting tool rather than to develop an approach, which increases a holistic understanding of the process chain. This holistic approach requires cybernetic models with emergent properties. Hence complexity in product design and order processing process is no longer controllable; the problem has to be reduced on a complexity level, where the main challenges still exist. By choosing a focus on the problem's complexity the technical challenge (see chapter 2.1) is addressed.

The approach presented in this paper starts the development of a product structure at the manufacturing environment. Therefore challenges in manufacturing processes 
first have to be solved so they are working stable and reliable. A product structure is the key to handling product complexity, whereas it can be treated on three levels: the product range level, product level and component level [10]. The understanding of the manufacturing processes and their link to product features helps to avoid complexity within the product design and order processing process. The cost and expense influence in manufacturing of a product feature has to be considered when designing a product. For example a variation of a product feature that causes a high cost impact because of different processes in the production should have a rather small range of variance [5]. This effect is called the variance sensitiveness and is a degree for the cost impact of a process in dependency of the product feature variance. The degree of variance sensitiveness is high if additional features lead to a high increase of process costs [23].

The presented approach will be used for the identification and detection of these process characteristics and their connection on the product features. The approach is divided in the following steps:

1. A target system for the product design has to be defined. Possible target systems can be product flexibility, increasing product economic efficiency or a higher degree of standardization.

2. A product range within an existing product program has to be chosen for the starting phase. This simplification limits the solution space and therefore reduces the necessary complexity.

3. The process chain of the selected products in manufacturing has to be analyzed. As a result main process chains are identified in production.

4. Within the main process chain a stable working process chain has to be selected. This process chain has to be able to manufacture a significant part of a product range and be insusceptible to changing process requirements due to varying products. The selected process chain is the basis for standardized manufacturing processes, which is characterized by short throughput times and leveled process times [24].

5. The selected process chain is used to identify the product components that are produced on this selected process chain by analyzing the corresponding working schedules.

6. A CAD-model based comparison of the selected components and the overall product components of the product program is used to determine further product components that can be produced on this process chain. The CAD-model comparison is supported by a knowledge based classification system for product data [25].

7. The overall received products are used to identify those product features, which make the products producible on the selected process chain. These product features have to be directly linked to the critical process characteristics. This step creates the connection between product and process feature which leads to the constituent product and process features.

8. Deriving design rules for a product structure that can be manufactured on a stable process chain. 


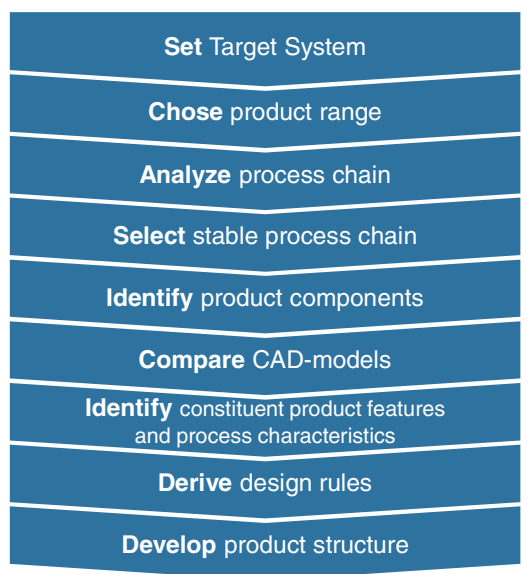

Fig. 2. Sequences of the presented approach

9. Consolidation of customer and market needs and design guidelines to develop a product structure which is based on a production-technical solution space.

The common understanding from engineers, production engineers and manufacturer of the dependency of product and process is the prerequisite to solve the research challenge. The aim is to develop a product structure for rotational products that is adapted for manufacturing processes and therefore enabling a cost-effective production. The presented method identifies product features that have a large impact on production costs by quantifying the expenses in manufacturing processes. The developed product structure has the aim to provide a maximum of product individuality by simultaneously standardize the manufacturing processes. After all the product development process is able to provide customized product solutions by using standardized and stabile processes. Elements of mass production such as in-line production are applied to the production of highly customized products. This puts companies into the position to design cost-effective products and production. A technological and production-related flexibility is important to fulfill the growing needs of global markets and to deal with the increased dynamic in the product development process as well as the supply chain within the order process. By applying this concept product and process know-how is constantly available from manufacturing to engineering and development. As a result employees got a persistent view on the product development process as they can now control the complexity of product features and process characteristics.

\section{Conclusions and Outlook}

The stated approach develops a product-structure that is aligned on the company's production. The technical challenge in dealing with product complexity is addressed by focusing on a definite process chain in manufacturing. The research challenge is 
addressed by the understanding of the link between process characteristics and product features. This is the basis to develop standardized processes in administration and stabile structures in manufacturing. Within the project "Design of innovative modular product platform and value added structures - GiBWert" (see www.gibwert.de), funded by the German Federal Ministry of Education and Research (BMBF), a method to systematically link product and process data will be implemented. The aim of this project is a constant product and process tracking system, which realizes complexity restrictions in the product development process. A fundamental part of the research project is to develop a method of detecting and evaluate the variance sensitivity of the production processes.

A validation is still going on at a small business of the machinery and plant engineering that is developing technical solutions for power train and transmission technologies. Process characteristics and product features are now to identify, to classify and to validate. Next exemplary products are used to identify their product features such as Diameter, bore holes, construction materials and surface qualities. After that proper process characteristics such as process times and tool insert have to be analyzed and then linked to the product features. The creation of a constituent product feature model existing of product features and process characteristics will be the next step.

Acknowledgements. The research and development project "Design of innovative modular product platforms and value added structures- GiBWert" is funded by the German Federal Ministry of Education and Research (BMBF) within the Framework Concept "Research for Tomorrow's Production" and managed by the Project Management Agency Karlsruhe (PTKA). The main research objective is to develop a product development process for modular product platforms and a holistic method to evaluate possible design scenarios. The author is responsible for the contents of this publication.

\section{References}

1. Brecher, C.: Integrative Production Technology for High-Wage Countries. Springer, Berlin (2011)

2. Wiendahl, H.P.: Betriebsorganisation für Ingenieure, 7th edn. Hanser, München (2010)

3. Hahn, D., Laßmann, G.: Produktionswirtschaft - Controlling industrieller Produktion. Band 1 \& 2: Grundlagen, Führung und Organisation, Produkte und Produktprogramm, Material und Dienstleistungen, Prozesse. Physica Verlag, Heidelberg (1999)

4. Schuh, G., Potente, T., Fuchs, S., Schmitz, S.: Wertstromorientierte Produktionssteuerung Interaktive Visualisierung durch IT-tools zur Bewertung der Logistik- und Produktionsleistung. wt Werkstattstechnik Online Jg. 102, H. 4 (2012)

5. Cai, Y.L., Nee, A.Y.C., Lu, W.F.: Platform Differentiation Plan for Platform Leverage Across Market Niches. Annals of the CIRP 57(1), 141-144 (2008)

6. Farrell, R., Simpson, T.W.: Product platform design to improve commonality in custom products. Journal of Intelligent Manufacturing 14, 541-556 (2003) 
7. Gao, F., Xiao, G., Simpson, T.W.: Module-scale-based Product Platform Planning Res. Eng. Des. 20(2), 129-141 (2009)

8. Lindemann, U., Maurer, M., Braun, T.: Structural Complexity Management - An Approach for the Field of Product Design. Springer, Berlin (2009)

9. Pimmler, T., Eppinger, S.: Integration Analysis of product decompositions. Massachusetts Institute of Technology, Cambridge (1994)

10. Ericsson, A., Erixon, G.: Controlling Design Variants: Modular Product Platforms, ASM, New York (1999)

11. Pahl, G., Beitz, W., Feldhusen, J., Grote, K.-H.: Konstruktionslehre, Grundlagen. Springer, Berlin (2007)

12. Kusiak, A., Huang, C.: Development of Modular Products. IEEE Transactions on Components, Packaging and Manufacturing Technology - Part A 19(4) (December 1996)

13. Kumar, D., Chen, W., Simpson, T.W.: A market-driven approach to product family design. International Journal of Production Research 47(1), 71-102 (2009)

14. Martin, M.V., Ishii, K.: Design for variety: developing standardized and modularized product platform architectures. Research in Engineering Design 13(4), 213-235 (2002)

15. Herstatt, C.: Management von technologiegetriebenen Entwicklungsprojekten, Hamburg (2000)

16. Köbler, J.: Modell einer wandlungsfähigen Organisation produzierender Unternehmen, Diss Univ. Stuttgart. Jost-Jetter Verlag, Heimsheim (2006)

17. Schuh, G., Arnoscht, J., Rudolf, S., Korthals, K.: Modular chassis product platform considering variable quantities for an economical electric vehicle production. WGP Konferenz, Berlin (2011)

18. Arnoscht, J.: Beherrschung von Komplexität bei der Gestaltung von Baukastensystemen, Diss. RWTH Aachen, Apprimus Verlag (2011)

19. Thome, R.: Business Software. ERP, SCM, APS, MES - was steckt hinter dem Begriffsdschungel der Business-Software-Lösungen. Lehrstuhl für BWL und Wirtschaftinformatik, Mainfränkisches Electronic Commerce Kompetenzzentrum, Würzburg (2007)

20. Schuh, G., Stich, V., Brosze, T., Fuchs, S., Pulz, C., Quick, J., Schürmeyer, M., Bauhoff, F. High Resolution Supply Chain Management - Optimised Processes based on SelfOptimizing Control Loops and Real Time Data. Production Engineering, Special Issue 1 (2011a)

21. Spur, G., Krause, F.: Das virtuelle Produkt. Management der CAD-Technik. Hanser, München (1997)

22. Beckert, B., Hudetz, W.: Stand und Potenzial produktnaher Datenverarbeitung. PPS Management 7(2), 35-39 (2002)

23. Schuh, G., Arnoscht, J., Bender, D., Bohl, A., Leiters, M., Pokraka, G., Rudolf, S., Schöning, S., Schulz, J., Vogels, T.: Lean Innovation mit Ähnlichkeitsmodellen, Aachen (2011)

24. Schuh, G., Potente, T., Fuchs, S., Thomas, C.: Interactive visualization in production control. In: 2011 17th International Conference on Concurent Enterprising, ICE (2011)

25. Weisskopf, J.: Automatische Produktdatenklassifikation in heterogenen Datenbeständen, Diss. Universität Karlsruhe (TH) (2002) 